\title{
PENGARUH KEMAMPUAN INTELEKTUAL DAN ETOS KERJA TERHADAP KINERJA PEGAWAI PADA KANTOR PELAYANAN KEKAYAAN NEGARA DAN LELANG PEMATANGSIANTAR
}

\author{
Oleh: \\ Remalia Samosir \\ S1 Manajemen \\ Darwin Lie, Marisi Butarbutar, Stefi Inggrid Thressa
}

Abstraksi

Adapun rumusan masalah penelitian ini adalah bagaimana pengaruh kemampuan intelektual dan etos kerja terhadap kinerja pegawai pada Kantor Pelayanan Kekayaan Negara dan Lelang Pematangsiantar. Penelitian ini dilakukan dengan menggunakan desain penelitian kepustakaan dan lapangan. Jenis data yang digunakan dalam penelitian ini adalah data kualitatif dan data kuantitatif. Sumber data adalah data primer dan data sekunder. Populasi pada penelitian ini adalah pegawai pada Kantor Pelayanan Kekayaan Negara dan Lelang Pematangsiantar yang berjumlah 30 orang, dan sampel yang digunakan adalah keseluruhan dari populasi. Pengumpulan data dilakukan dengan kuesioner, wawancara, dan dokumentasi. Teknik analisis data yang digunakan adalah regresi linear berganda, koefisien korelasi, koefisien determinasi, dan pengujian hipotesis dengan uji $\mathrm{F}$ dan uji t.

Hasil penelitian ini dapat disimpulkan sebagai berikut: 1. Kemampuan intelektual sudah tinggi, etos kerja sangat tinggi dan kinerja pegawai sangat baik. 2. Hasil analisis regresi adalah $\hat{Y}=38,572+0,631 X_{1}+0,390 X_{2}$, artinya kemampuan intelektual dan etos kerja berpengaruh positif terhadap kinerja pegawai. 3. Hasil analisis koefisien korelasi diperoleh nilai $r=0,725$, artinya terdapat hubungan yang kuat dan positif antara kemampuan intelektual, etos kerja dengan kinerja pegawai pada Kantor Pelayanan Kekayaan Negara dan Lelang Pematangsiantar. Baik tidaknya kinerja pegawai sebesar 52,6\% dapat dijelaskan oleh kemampuan intelektual dan etos kerja. 4. Hasil uji hipotesis menyatakan $\mathrm{H}_{0}$ ditolak, artinya kemampuan intelektual dan etos kerja berpengaruh positif dan signifikan terhadap kinerja pegawai pada Kantor Pelayanan Kekayaan Negara dan Lelang Pematangsiantar baik secara simultan maupun parsial.

Adapun saran dari hasil penelitian ini adalah untuk meningkatkan kemampuan intelektual pegawai, instansi sebaiknya memberikan peluang untuk pendidikan lebih lanjut dan memberikan pelatihan secara rutin agar pegawai mahir dalam menyelesaikan tugasnya. Untuk meningkatkan etos kerja pegawai, instansi sebaiknya meningkatkan etos kerja bagi pegawainya agar tercipta semangat kerja yang tinggi sehingga pegawai dapat memfungsikan etos kerja yang ada dalam dirinya untuk peningkatan kualitas hasil kerjanya. Sedangkan untuk mengoptimalkan kinerja pegawai, instansi sebaiknya memberikan kesempatan kepada pegawai untuk berinovasi sehingga menimbulkan kreativitas dalam bekerja.

Kata Kunci: Kemampuan Intelektual, Etos Kerja dan Kinerja Pegawai.

\section{Abstraction}

As for this research problem formula is how intellectual abilities and ethic of work influence to employee performance at Kantor Pelayanan Kekayaan Negara dan Lelang Pematangsiantar. This research was done by using design of literature and field research. The type of data used in this research is qualitative and quantitative data. Sources of data are primary and secondary data. The population of this research are 30 people which one the employees of Kantor Pelayanan Kekayaan Negara dan Lelang Pematangsiantar, and sample all of us population. Data was collected by questionary, interview and documentation. The technique of analyzing is multiple linear regression, coefficient correlation, coefficient determination and hypothesis testing by $F$ test and $t$ test.

The results of this study can be summarized as follows: 1. The intellectual abilities is high, the ethic of work is very high and the employee performance is excellent. 2 . The results of regression analysis is $\hat{Y}=38,572$ $+0,631 X_{1}+0,390 X_{2}$, its means that intellectual ability and ethic of work had a positive effect on employee performance 3. The results of the analysis correlations get value $r=0,725$, its means that there is a strong and positive relationship between intellectual ability, ethic of work to the employee performance at Kantor Pelayanan Kekayaan Negara dan Lelang Pematangsiantar. The level of employee performance can be explained by intellectual ability and ethic of work as big as 52,6\%. 4. The results of testing the hypothesis $H_{0}$ is rejected, its means that intellectual ability and ethic of work had a positive and significant effect to the employee performance at Kantor Pelayanan Kekayaan Negara dan Lelang Pematangsiantar auction both of simultaneous or partial.

The suggestion of this research is to improve the intellectual abilities, the agency should provide opportunities for further education and training on a regular basis so that employee are proficient in completing its task. To improve employee ethic of work, we recommend that agencies should improve ethic of work for employees in order to create high morale so that employees can enable a work ethic that was in him to improve 
the quality of his work. Meanwhile, to optimize the performance of employees, agencies should the provide the opportunity for employees to innovate in order to rise the creativity of work.

\section{Keywords: Intellectual Abilities, Ethic of Work and Employee Performance}

\section{A. PENDAhuluan}

1.Latar Belakang Masalah

Kantor Pelayanan Kekayaan Negara dan

Lelang Pematangsiantar adalah sebuah instansi yang bergerak pada pelayanan publik dalam hal kekayaan negara, pengelolaan piutang dan lelang. Kantor Pelayanan Kekayaan Negara dan Lelang Pematangsiantar perlu memperhatikan kinerja pegawai sebagai salah satu upaya yang menentukan keberhasilan penyelenggaraan program pemerintah.

Ada beberapa hal yang mempengaruhi kinerja pegawai Kantor Pelayanan Kekayaan Negara dan Lelang Pematangsiantar. Hal ini dapat dilihat dari dua aspek yaitu sasaran kinerja pegawai dan perilaku kerja. Sasaran kinerja pegawai meliputi kuantitas, kualitas, waktu dan biaya. Sedangkan Perilaku kerja meliputi orientasi pelayanan, integritas, komitmen, disiplin, kerjasama, dan kepemimpinan. Dari hasil wawancara pada bagian umum Kantor Pelayanan Kekayaan Negara dan Lelang Pematangsiantar, bahwa secara umum dari 30 pegawai terdapat kinerja pegawai yang sangat baik adalah $75 \%$, kategori baik sebanyak $20 \%$, dan yang cukup baik $5 \%$.

Salah satu faktor yang mempengaruhi kinerja pegawai tersebut, adalah kemampuan intelektual pegawai itu sendiri. Adapun dimensi kemampuan intelektual adalah kemahiran berhitung, pemahaman verbal, kecepatan konseptual, penalaran induktif, penalaran deduktif, visualisasi ruang, dan ingatan. Fenomena Kemampuan Intelektual pegawai Kantor Pelayanan Kekayaan Negara dan Lelang Pematangsiantar terjadi pada dimensi pemahaman verbal dan kecepatan konseptual, hal ini dapat dilihat dari pegawai yang kurang memiliki kosakata bahasa baku sehingga kurang mampu untuk menyampaikan pendapat pada saat rapat. Pada dimensi kecepatan konseptual, pegawai Kantor Pelayanan Kekayaan Negara dan Lelang Pematangsiantar kurang memiliki kemampuan untuk memecahkan masalah yang dihadapi secara mandiri serta cepat dan tepat.

Sedangkan pada dimensi kemahiran berhitung, penalaran induktif, penalaran deduktif, visualisasi ruang, serta ingatan, pegawai Kantor Pelayanan Kekayaan Negara dan Lelang Pematangsiantar memiliki kemampuan untuk menggunakan logika dalam menjalankan tugas, mampu bekerja dengan baik, mampu menyelesaikan pekerjaan sesuai dengan urutan logis penyelesaiannya, serta mampu mengingat suatu pekerjaan dan menerapkan pengalaman dalam mempercepat proses penyelesaian pekerjaan.

Selain kemampuan intelektual, etos kerja juga dapat mempengaruhi kinerja pegawai. Adapun dimensi etos kerja meliputi rahmat, amanah, panggilan, aktualisasi, ibadah, seni, kehormatan, dan pelayanan. Fenomena etos kerja pegawai Kantor Pelayanan Kekayaan Negara dan Lelang Pematangsiantar terjadi pada dimensi pekerjaan sebagai rahmat dan ibadah, hal ini ditunjukkan dari sikap pegawai yang terkadang kurang serius dalam melakukan tugasnya.

Sedangkan pada dimensi amanah, panggilan, aktulisasi, seni, kehormatan, dan pelayanan, pegawai Kantor Pelayanan Kekayaan Negara dan Lelang Pematangsiantar memiliki perilaku yang baik dimana pegawai memfungsikan etos kerja yang ada dalam dirinya dan menjadikan semangat dari dalam hati sebagai kekuatan penggerak yang konsisten untuk menghasilkan pekerjaan yang produktif, kreatif, dan mempunyai etos kerja baik yang dapat mendorong dirinya untuk mampu bekerja secara paripurna, bertanggungjawab, rendah hati, tekun, untuk meraih kinerja yang optimal.

\section{Rumusan Masalah}

a. Bagaimana gambaran kemampuan intelektual, etos kerja dan kinerja pegawai pada Kantor Pelayanan Kekayaan Negara dan Lelang Pematangsiantar.

b. Bagaimana pengaruh kemampuan intelektual dan etos kerja terhadap kinerja pegawai pada Kantor Pelayanan Kekayaan Negara dan Lelang Pematangsiantar baik secara simultan maupun parsial.

\section{Tujuan Penelitian}

a. Untuk mengetahui gambaran kemampuan intelektual, etos kerja dan kinerja pegawai pada Kantor Pelayanan Kekayaan Negara dan Lelang Pematangsiantar.

b. Untuk mengetahui pengaruh kemampuan intelektual dan etos kerja terhadap kinerja pegawai pada Kantor Pelayanan Kekayaan Negara dan Lelang Pematangsiantar baik secara simultan maupun parsial.

\section{Metode Penelitian}

Yang menjadi objek penelitian adalah Pegawai Kantor Pelayanan Kekayaan Negara dan Lelang Pematangsiantar yang terletak di Jalan Sisingamagaraja No.79 Pematangsiantar - 21147; Telepon (0622) 431156, (0622) 5890156; Faksimile: (0622) 431156; Email: kpknlpematangsiantar@gmail.com. Populasi adalah adalah seluruh pegawai pada Kantor Pelayanan Kekayaan Negara dan Lelang Pematangsiantar yang berjumlah 30 orang.

Adapun desain penelitian yang digunakan dalam penulisan skripsi ini adalah Penelitian Kepustakaan (Library Research) dan Penelitian Lapangan (Field Research). Teknik pengumpulan data yang dilakukan penulis dalam penelitian ini adalah berupa Kuesioner, Wawancara dan Dokumentasi. Jenis data yang digunakan dalam penelitian ini adalah jenis data kualitatif dan data kuantitatif. Hasil data yang diperoleh dari lapangan 
akan dianalisis secara deskriptif baik bersifat kualitatif dan kuantitatif.

\section{B. LANDASAN TEORI}

1. Manajemen Sumber Daya Manusia

Menurut Dessler (2006:5), manajemen sumber daya manusia adalah proses memperoleh, melatih, menilai dan memberikan kompensasi kepada karyawan, memperhatikan hubungan kerja mereka, kesehatan dan keamanan, serta masalah keadilan. Menurut Mathis dan John (2006:3), manajemen sumber daya manusia adalah rancangan sistem-sistem formal dalam sebuah organisasi untuk memastikan penggunaan bakat manusia secara efektif dan efisien guna mencapai tujuan organisasi. Menurut beberapa pendapat para ahli di atas maka dapat disimpulkan bahwa manajemen sumber daya manusia adalah segala usaha maupun bakat yang ada pada diri seorang individu yang dapat dimanfaatkan untuk kepentingan bersama demi kelangsungan hidup manusia itu sendiri dengan berjalannya tujuan organisasi.

\section{Kemampuan Intelektual}

Menurut Goleman (2002:512), kemampuan intelektual adalah kemampuan untuk mengenali perasaan kita sendiri dan perasaan orang lain, kemampuan memotivasi diri sendiri dan kemampuan mengelola emosi dengan baik pada diri sendiri dan dalam hubungan dengan orang lain. Sedangkan menurut Robbins (2001:46), kemampuan intelektual adalah kemampuan mental yang diperlukan untuk menjalankan kegiatan mental. Kemampuan intelektual akan menjadikan individu mempunyai kompetensi untuk dapat melaksanakan tugastugasnya dengan tanpa keraguan sehingga menghasilkan kinerja yang lebih baik. Berdasarkan uraian di atas, penulis mengambil kesimpulan bahwa kemampuan intelektual adalah kapasitas umum dari kesadaran individu untuk berfikir, menyesuaikan diri, mengelola emosi, dan memecahkan masalah yang dihadapi secara bijaksana serta cepat dan tepat.

Dimensi kemampuan intelektual yang dikemukakan oleh Robbins (2003:51), yang dapat dijadikan indikator pengukuran kemampuan intelektual dalam pekerjaan, yaitu: kemahiran berhitung, pemahaman verbal, kecepatan konseptual, penalaran induktif, penalaran deduktif, visualisasi ruang, dan ingatan (memori). Sedangkan Gibson (2000:55), menjelaskan ada beberapa kemampuan yang harus dimiliki oleh pegawai untuk mencapai efektivitas dan efisiensi kerja yaitu kemampuan berhubungan antar manusia (berinteraksi), kemampuan konseptual, dan kemampuan teknis. Berdasarkan uraian di atas, penulis dapat menyimpulkan bahwa dimensi pengukuran kemampuan dapat dilihat dari kemampuan berinteraksi antar pegawai dalam suatu organisasi, kemampuan untuk mengikuti rencana kerja, kemampuan menentukan keputusan, serta pemahaman dan penalaran dibidang numerik, bentuk, dan bahasa.

\section{Etos Kerja}

Menurut Anoraga (2009:282), etos kerja merupakan suatu pandangan dan sikap suatu bangsa atau umat terhadap kerja. Bila individu-individu dalam komunitas memandang kerja sebagai suatu hal luhur bagi eksistensi manusia, maka etos kerjanya akan cenderung tinggi. Sedangkan menurut Tasmara (2002:73), etos kerja adalah segala ilmu kebaikan dan keburukan yang ada di dalam diri manusia yang merupakan pertimbangan perbuatan dalam melakukan pekerjaan yang akan tampak dalam sikap dan tingkah lakunya. Berdasarkan beberapa pendapat di atas, penulis menyimpulkan bahwa etos kerja merupakan seperangkat sikap atau pandangan mendasar yang dipegang pegawai untuk menilai berkerja sebagai suatu hal yang positif bagi peningkatan kualitas kehidupan, sehingga mempengaruhi perilaku kerjanya dalam organisasi.

Menurut Sinamo (2005:323), ada delapan aspek etos kerja untuk mencapai kesuksesan yaitu : kerja adalah rahmat, kerja adalah amanah, kerja adalah panggilan, kerja adalah aktualisasi, kerja adalah ibadah, kerja adalah seni, kerja adalah kehormatan, dan kerja adalah pelayanan. Sedangkan menurut Anoraga (2009:302), karakteristik etos kerja yaitu antara lain sebagai berikut : aspek dari dalam, aspek motif sosial, dan aspek persepsi. Berdasarkan uraian di atas, dapat disimpulkan bahwa pada dasarnya manusia adalah pencari kesuksesan. Untuk mencapai kesuksesan itu, pegawai harus memperhatikan aspek-aspek yang dapat mempengaruhi etos kerja yaitu bekerja dengan tulus dan penuh syukur, bekerja dengan penuh integritas, bekerja degan benar dan penuh tanggungjawab, bekerja keras dengan penuh semangat, bekerja cerdas penuh kreatif, bekerja serius penuh kecintaan, dan bekerja paripurna penuh kerendahan hati.

\section{Kinerja}

Menurut Rivai (2005:14), Kinerja merupakan hasil atau tingkat keberhasilan seseorang secara keseluruhan selama periode tertentu dalam melaksanakan tugas dibandingkan dengan berbagai kemungkinan, seperti standard hasil kerja, target atau sasaran yang telah disepakati bersama. Menurut Mathis dan John (2006:113), kinerja adalah suatu hasil kerja yang dicapai seseorang dalam melaksanakan tugas-tugas yang dibebankan kepadanya yang disarankan atas pengalaman, kecakapan, kesungguhan serta waktu. Berdasarkan uraian di atas, penulis dapat menyimpulkan bahwa kinerja merupakan prestasi kerja atau hasil kerja yang dicapai oleh seorang pegawai dalam melaksanakan tugas-tugas yang dibebankan kepadanya sesuai dengan tanggung jawab yang diberikan serta berdasarkan pengalaman kecakapan yang dimiliki.

Menurut Mathis dan John (2006:378), kinerja memiliki lima dimensi yaitu: kuantitas dari hasil, kualitas dari hasil, ketepatan waktu dari hasil, kehadiran, dan Kemampuan bekerjasama. Secara umum, penilaian prestasi kerja Pegawai Negeri Sipil dibagi dalam 2 (dua) unsur yaitu : Sasaran Kerja 
Pegawai (SKP) meliputi unsur: kuantitas, kualitas, waktu, dan biaya, dan perilaku kerja meliputi: orientasi pelayanan, integritas, komitmen, disiplin, kerjasama, dan kepemimpinan. Berdasarkan uraian di atas, penulis menyimpulkan bahwa penilaian kinerja merupakan faktor penting untuk suksesnya manajemen kinerja. Penilaian kinerja bukanlah tujuan akhir, melainkan merupakan alat untuk menghasilkan manajemen yang lebih efisien dengan dasar-dasar yang tersedia dalam pengukuran kinerja dan dapat meningkatkan kinerja.

\section{PEMBAHASAN}

\section{Analisa}

\section{a. Deskriptif Kualitatif}

Analisis deskriptif kualitatif dimaksudkan untuk mendapatkan gambaran atau deskripsi mengenai tanggapan dari pelanggan mengenai pengaruh kemampuan intelektual dan etos kerja terhadap kinerja pegawai pada Kantor Pelayanan Kekayaan Negara dan Lelang Pematangsiantar. Adapun penetapan kriteria nilai rata-rata jawaban dari responden tersebut dimasukkan kedalam kelaskelas interval dimana penentuan intervalnya memakai rumus sebagai berikut:

Interval Kelas $=$ Nilai Tertinggi - Nilai Terendah Jumlah Kelas

Dari rumus di atas dapat diperoleh interval kelas 0,8 sehingga berlaku ketentuan indikator dengan hasil sebagai berikut:

Tabel 1

Nilai Interval dan Indikator Jawaban Responden

\begin{tabular}{|c|c|c|c|}
\hline $\begin{array}{c}\text { Nilai } \\
\text { Interval }\end{array}$ & \multicolumn{3}{|c|}{ Indikator } \\
\hline $1,00-1,80$ & Komunikasi & Disiplin kerja & Kinerja Kerja \\
\hline $1,81-2,60$ & Tidak Baik & Tidak Baik & Tidak Baik \\
\hline $2,61-3,40$ & Cukup Baik & Cukup Baik & Cukup Baik \\
\hline $3,41-4,20$ & Baik & Baik & Baik \\
\hline $4,21-5.00$ & Sangat Baik & Sangat Baik & Sangat Baik \\
\hline
\end{tabular}

Sumber : hasil pengolahan data

1) Gambaran Kemampuan Intelektual Pada Kantor Pelayanan Kekayaan Negara dan Lelang Pematangsiantar

Dari hasil analisa, untuk dimensi kemahiran berhitung pada indikator tingkat kemampuan pegawai dalam berhitung secara tepat berada pada rata-rata 4,27 dengan kriteria jawaban sangat tinggi. Hal ini disebabkan pegawai yang memiliki kemampuan berhitung dengan baik dan didukung dengan latar belakang pendidikan pegawai. Pada indikator kemampuan pegawai dalam berhitung dengan cepat berada pada rata-rata 4,07 dengan kriteria jawaban tinggi. Hal ini disebabkan setiap pegawai selalu berusaha untuk menyelesaikan masalah dengan baik, hal ini juga dapat dilihat dari kecepatan dan kemaksimalan pegawai dalam menyelesaikan tugas. Selanjutnya pada indikator kemampuan pegawai dalam mengerjakan tugas berada pada rata-rata 4,33 dengan kriteria jawaban sangat tinggi. Hal ini disebabkan hampir semua pegawai mampu dalam menyelesaikan pekerjaan dengan baik dan tepat waktu.
Pada dimensi pemahaman verbal, untuk indikator kemampuan pegawai dalam memahami apa yang dibaca berada pada rata-rata 4,33 dengan kriteria jawaban sangat tinggi. Hal ini disebabkan hampir semua pegawai dapat membaca dan dapat memahami apa yang dibacanya, hal ini dapat dilihat dari pekerjaan yang dapat diselesaikan dengan baik meskipun bahasa yang dipakai tidak selalu sama. Pada indikator kemampuan pegawai dalam memahami apa yang didengar berada pada rata-rata 4,23 dengan kriteria jawaban sangat tinggi. Hal ini disebabkan pegawai mendengar dengan baik sehingga memahami apa yang didengarnya dan menghasilkan pekerjaan yang baik. Selanjutnya pada indikator tingkat kemampuan pegawai dalam menyampaikan pendapat berada pada rata-rata 3,97 dengan kriteria jawaban tinggi. Hal ini disebabkan sebagian besar pegawai mampu menyampaikan pendapat pada saat acara resmi maupun non resmi untuk kemajuan perusahaan.

Pada dimensi kecepatan konseptual, untuk indikator kemampuan pegawai dalam mengenali kemiripan suatu permasalahan berada pada rata-rata 4,00 dengan kriteria jawaban tinggi. Selanjutnya pada indikator kemampuan berfikir pegawai dalam menyelesaikan tugas berada pada rata-rata 3,83 dengan kriteria jawaban tinggi. Hal ini disebabkan pegawai memiliki kemampuan untuk menyelesaikan setiap permasalahan sekalipun memiliki banyak kemiripan. Pada indikator kemampuan pegawai mengidentifikasi suatu permasalahan berada pada rata-rata 4,23 dengan kriteria jawaban sangat tinggi.

Pada dimensi penalaran induktif, untuk indikator kemampuan pegawai dalam mengenali masalah dan menyelesaikan berdasarkan urutan logis berada pada rata-rata 4,20 dengan kriteria tinggi. Hal ini disebabkan kemampuan yang dimiliki pegawai dalam mengenali setiap permasalahan dan menyelesaikan setiap tugasnya dengan baik. Pada usaha yang dilakukan dalam menyelesaikan pekerjaan yang sulit berada pada rata-rata 4,33 dengan kriteria jawaban sangat tinggi. Kemudian pada indikator kemampuan pegawai dalam menyelesaikan pekerjaan berada pada rata-rata 4,27 dengan kriteria jawaban sangat tinggi. Hal ini disebabkan pegawai memiliki usaha dan kemampuan dalam menyelesaikan setiap pekerjaan dengan baik dan tepat waktu.

Pada dimensi penalaran deduktif, untuk indikator tingkat logika pegawai dalam menilai suatu argumen berada pada rata-rata 4,23 dengan kriteria jawaban sangat tinggi. Untuk indikator kecakapan pegawai dalam menjalankan tugas berada pada ratarata 4,27 dengan kriteria jawaban sangat tinggi. Hal ini disebabkan tingkat kemampuan logika yang dimiliki pegawai dalam menjalankan setiap tugas yang diberikan. Selanjutnya indikator kemampuan pegawai dalam bekerja secara fleksibel berada pada rata-rata 4,00 dengan kriteria jawaban tinggi. Hal ini disebabkan pegawai memiliki kemampuan untuk bekerja dengan baik dan fleksibel.

Pada dimensi visualisasi ruang, untuk indikator kemampuan pegawai dalam 
membayangkan suatu masalah dan cara menyelesaikannya berada pada rata-rata 4,07 dengan kriteria jawaban tinggi, kemampuan pegawai dalam membayangkan suatu objek, seandainya posisi dalam ruangan diubah berada pada rata-rata 4,20 dengan kriteria jawaban tinggi, kemampuan pegawai dalam mengerjakan tugas dengan ruangan kerja yang diubah berada pada rata-rata 4,00 dengan kriteria jawaban tinggi. Hal ini disebabkan dengan berubahnya posisi ruangan tidak mempengaruhi keseriusan dan kemampuan berfikir pegawai dalam menyelesaikan tugas

Pada dimensi ingatan, untuk indikator kemampuan pegawai untuk mengenang kembali pengalaman kerja sebagai pembelajaran berada pada rata-rata 4,20 dengan kriteria jawaban tinggi, ingatan pegawai terhadap suatu pekerjaan yang sudah lama tidak dikerjakan berada pada rata-rata 4,07 dengan kriteria jawaban tinggi. Hal ini disebabkan pegawai mampu mengenang kembali pengalaman dalam bekerja dan tetap mengingat pekerjaan sekalipun sudah lama tidak dikerjakan. Untuk indikator memori pegawai dalam mengingat suatu pekerjaan berada pada rata-rata 4,27 dengan kriteria jawaban tinggi. Hal ini disebabkan tuntutan pekerjaan untuk mengingat pekerjaan supaya pekerjaan tidak terbengkalai.

\section{2) Gambaran Etos Kerja Pada Kantor Pelayanan Kekayaan Negara dan Lelang \\ Pematangsiantar}

Dari hasil analisa, dapat dilihat bahwa pada dimensi kerja adalah rahmat dengan indikator pegawai memiliki rahmat untuk mau bekerja dengan tulus diperoleh nilai rata-rata 4,40 dengan kriteria jawaban sangat tinggi, hal ini terjadi karena pegawai memiliki keyakinan untuk melakukan pekerjaannya dengan tulus dan ikhlas. Pada indikator pegawai memiliki rahmat untuk mau bekerja dengan penuh syukur diperoleh nilai rata-rata 4,07 dengan kriteria jawaban tinggi. Pada indikator pegawai memiliki rahmat untuk patuh dalam bekerja diperoleh nilai rata-rata 4,43 dengan kriteria jawaban sangat tinggi. Hal ini terjadi karena pegawai bersyukur atas pekerjaan yang diberikan dan patuh untuk mengerjakan setiap pekerjaan yang diterimanya.

Pada dimensi kerja adalah amanah dengan indikator pegawai memiliki amanah untuk bekerja dengan berkomitmen diperoleh nilai rata-rata 4,50 dengan kriteria jawaban sangat tinggi, hal ini terjadi karena pegawai memiliki komitmen yang tinggi untuk bekerja dengan baik. Pada indikator pegawa memiliki amanah untuk bekerja dengan penuh tanggungjawab diperoleh nilai rata-rata 4,43 dengan kriteria jawaban sangat tinggi. Pada indikator pegawai memiliki amanah untuk bekerja dengan benar diperoleh nilai rata-rata 4,40 dengan kriteria jawaban sangat tinggi. Hal ini disebabkan pegawai memiliki amanah untuk melakukan pekerjaan dengan benar dan penuh tanggungjawab.

Pada dimensi kerja adalah panggilan dengan indikator pegawai memiliki panggilan untuk mau bekerja dengan tuntas diperoleh nilai rata-rata 4,57 dengan kriteria jawaban sangat tinggi. Hal ini terjadi karena pegawai mau menerima dan menyelesaikan tugas dengan tuntas. Pada indikator pegawai memiliki panggilan untuk mau bekerja dengan penuh integritas diperoleh nilai rata-rata 4,20 dengan kriteria jawaban tinggi. Pada indikator pegawai memiliki panggilan untuk bekerja dengan segenap hati diperoleh nilai rata-rata 4,50 dengan kriteria jawaban sangat tinggi. Hal ini terjadi karena pegawai memiliki panggilan untuk bekerja segenap hati dan penuh integritas.

Pada dimensi kerja adalah aktualisasi dengan indikator pegawai memiliki aktualisasi untuk mau bekerja keras diperoleh nilai rata-rata 4,47 dengan kriteria jawaban sangat tinggi. Pada indikator pegawai memiliki aktualisasi untuk mau bekerja dengan penuh semangat diperoleh nilai rata-rata 4,40 dengan kriteria jawaban sangat tinggi. Pada indikator pegawai memiliki aktualisasi untuk mencapai target kerja diperoleh nilai rata-rata 4,40 dengan kriteria jawaban sangat tinggi. Hal ini terjadi karena pegawai mendorong dirinya untuk bertindak dan meraih kinerja dengan optimal dengan penuh semangat untuk menyelesaikan pekerjaan dan mencapai target kerja.

Pada dimensi kerja adalah ibadah dengan indikator pegawai memiliki ibadah untuk mau bekerja dengan serius diperoleh nilai rata-rata 4,23 dengan kriteria jawaban sangat tinggi. Hal ini terjadi karena pegawai memiliki keyakinan yang kuat untuk melayani pekerjaannya dengan serius. Pada indikator pegawai memiliki ibadah untuk mau bekerja dengan penuh kecintaan diperoleh nilai rata-rata 4,17 dengan kriteria jawaban tinggi. Pada indikator pegawai memiliki ibadah untuk mau bekerja dengan berkomitmen tinggi diperoleh nilai rata-rata 4,47 dengan kriteria jawaban sangat tinggi. Hal ini terjadi karena pegawai memiliki keyakinan yang kuat untuk bekerja dengan penuh kecintaan dan komitmen yang tinggi terhadap pekerjaannya.

Pada dimensi kerja adalah seni dengan indikator pegawai memiliki seni untuk mau bekerja dengan cerdas diperoleh nilai rata-rata 4,40 dengan kriteria jawaban sangat tinggi. Pada indikator pegawai memiliki seni untuk mau bekerja dengan penuh kreativitas diperoleh nilai rata-rata 4,57 dengan kriteria jawaban sangat tinggi. Hal ini terjadi karena pegawai mampu bekerja dengan cerdas dan kreatif dalam menyelesaikan masalah yang ada. Pada indikator pegawai memiliki seni dalam mewujudkan cita-cita diperoleh nilai rata-rata 4,47 dengan kriteria jawaban sangat tinggi. Hal ini terjadi karena pegawai memiliki seni untuk mewujudkan cita-citanya.

Pada dimensi kerja adalah kehormatan dengan indikator pegawai mempunyai kehormatan untuk mau bekerja dengan penuh keunggulan diperoleh nilai rata-rata 4,20 dengan kriteria jawaban tinggi. Hal ini terjadi karena pegawai memiliki kehormatan untuk bekerja dengan unggul. Pada indikator pegawai mempunyai kehormatan untuk mau bekerja dengan tekun diperoleh nilai rata-rata 4,47 dengan kriteria jawaban sangat tinggi. Pada indikator cara pegawai dalam meningkatkan wibawa 
diperoleh nilai rata-rata 4,47 dengan kriteria jawaban sangat tinggi. Hal ini terjadi karena pegawai memiliki sikap positif untuk bekerja dengan tekun sehingga meningkatkan wibawanya.

Pada dimensi kerja adalah pelayanan dengan indikator pegawai menerima pelayanan untuk mau bekerja paripurna diperoleh nilai rata-rata 4,17 dengan kriteria jawaban tinggi. Hal ini terjadi karena setiap pegawai menerima pelayanan yang baik sehingga pegawai bekerja sama atau bekerja paripurna dalam menyelesaikan pekerjaannya untuk kemajuan instansi. Pada indikator pegawai menerima pelayanan untuk mau bekerja dengan penuh kerendahan hati diperoleh nilai rata-rata 4,50 dengan kriteria jawaban sangat tinggi. Pada indikator pegawai menilai bekerja sebagai bentuk pelayanan diperoleh nilai rata-rata 4,13 dengan kriteria jawaban tinggi.

\section{Gambaran Kinerja Pegawai Pada Kantor Pelayanan Kekayaan Negara dan Lelang Pematangsiantar}

Dari hasil analisa, dapat dilihat bahwa untuk dimensi kuantitas pada indikator pegawai menyelesaikan pekerjaannya sesuai dengan prosedur diperoleh nilai rata-rata 4,63 dengan kriteria jawaban sangat baik karena setiap pegawai dituntut untuk menyelesaikan pekerjaannya sesuai dengan prosedur yang berlaku dalam instansi. Pada indikator pegawai dalam menangani volume pekerjaan yang luar biasa banyaknya diperoleh nilai rata-rata 4,20 dengan kriteria jawaban baik. Pada indikator tingkat pencapaian target kerja pegawai diperoleh nilai ratarata 4,37 dengan kriteria jawaban sangat baik. Hal ini terjadi karena pegawai antusias untuk mencapai target kerja yang baik sehingga pekerjaan berlebih tidak mempengaruhi sikap pegawai dalam bekerja.

Pada dimensi kualitas dengan indikator tingkat ketelitian pegawai dalam menyelesaikan tugas diperoleh nilai rata-rata 4,50 dengan kriteria jawaban sangat baik. Hal ini terjadi karena pegawai teliti dalam melakukan pekerjaannya. Pada indikator pegawai bekerja sesuai standar diperoleh nilai ratarata 4,33 dengan kriteria jawaban sangat baik. Pada indikator tingkat mutu hasil kerja pegawai diperoleh nilai rata-rata 4,43 dengan kriteria jawaban sangat baik. Hal ini terjadi karena pegawai teliti dan dapat menyelesaikan pekerjaan dengan hasil yang baik sesuai dengan batas waktu yang diberikan.

Pada dimensi ketepatan waktu dengan indikator pegawai dalam menyelesaikan pekerjaan tepat waktu diperoleh nilai rata-rata 4,40 dengan kriteria jawaban sangat baik. Pada indikator efisiensi waktu dalam menyelesaikan pekerjaan diperoleh nilai rata-rata 4,27 dengan kriteria jawaban sangat baik. Hal ini terjadi karena pegawai bersaing dengan positif untuk menyelesaikan pekerjaan mereka masig-masing. Pada indikator tingkat kehadiran pegawai dalam kantor diperoleh nilai rata-rata 4,57 dengan kriteria jawaban sangat baik. Hal ini terjadi karena pegawai hadir tepat waktu di kantor.

Pada dimensi biaya dengan indikator jumlah anggaran yang diberikan kepada pegawai diperoleh nilai rata-rata 4,63 dengan kriteria jawaban sangat baik. Pada indikator jumlah biaya yang diberikan untuk keperluan pegawai setiap tahunnya diperoleh nilai rata-rata 4,53 dengan kriteria jawaban sangat baik. Hal ini terjadi karena instansi memberikan kompensasi yang baik terhadap pegawainya yang sudah ditentukan perusahaan. Pada indikator kemampuan pegawai dalam mengalokasikan biaya pekerjaan diperoleh nilai rata-rata 4,67 dengan kriteria jawaban sangat baik. Hal ini terjadi karena instansi memberikan jaminan yang pasti kepada setiap pegawai pada masa tuanya.

Pada dimensi orientasi pelayanan dengan indikator tingkat pelayanan yang diberikan pegawai diperoleh nilai rata-rata 4,40 dengan kriteria jawaban sangat baik. Pada indikator ketepatan kualitas pelayanan pegawai diperoleh nilai rata-rata 4,57 dengan kriteria jawaban sangat baik. Pada indikator sikap pegawai saat memberikan pelayanan diperoleh nilai rata-rata 4,33 dengan kriteria jawaban sangat baik. Hal ini terjadi karena pegawai memberikan pelayanan yang baik kepada pelanggan tepat waktu.

Pada dimensi integritas dengan indikator etika pegawai dalam instansi diperoleh nilai rata-rata 4,67 dengan kriteria jawaban sangat baik. Hal ini terjadi karena pegawai dalam instansi memiliki etika yang baik. Pada indikator kemampuan pegawai dalam instansi diperoleh nilai rata-rata 4,37 dengan kriteria jawaban sangat baik. Hal ini terjadi karena pegawai memiliki kemampuan yang bagus dalam bekerja. Pada indikator konsistensi pegawai dalam bekerja diperoleh nilai rata-rata 4,67 dengan kriteria jawaban sangat baik. Hal ini terjadi karena pegawai Kantor Pelayanan Kekayaan Negara dan Lelang Pematangsiantar memiliki keinginan untuk bekerja dengan konsisten.

Pada dimensi komitmen dengan indikator komitmen pegawai diperoleh nilai rata-rata 4,63 dengan kriteria jawaban sangat baik. Pada indikator tingkat kesediaan pegawai dalam melakukan pekerjaan tanpa diperintah atasan diperoleh nilai rata-rata 4,53 dengan kriteria jawaban sangat baik. Hal ini terjadi karena pegawai mempunyai komitmen yang baik dalam melaksanakan tugasnya tanpa diperintah oleh atasan. Pada indikator sikap pegawai diperoleh nilai rata-rata 4,60 dengan kriteria jawaban sangat baik. Hal ini terjadi karena pegawai dalam instansi mempunyai sikap yang baik dan sopan.

Pada dimensi disiplin dengan indikator kewajiban pegawai dalam melaksanakan tugasnya diperoleh nilai rata-rata 4,60 dengan kriteria jawaban sangat baik. Pada indikator kedisiplinan pegawai dalam instansi diperoleh nilai rata-rata 4,63 dengan kriteria jawaban sangat baik. Hal ini terjadi karena pegawai mematuhi peraturan dan memiliki disiplin yang kuat untuk mematuhi setiap peraturan yang telah ditetapkan oleh instansi. Pada indikator pemberian sanksi oleh instansi jika ada pegawai yang tidak disiplin diperoleh nilai rata-rata 4,27 dengan kriteria jawaban sangat baik. Hal ini terjadi karena pimpinan tidak pandang buluh dalam memberikan sanksi kepada pegawai. 
Pada dimensi kerjasama dengan indikator hubungan kerjasama antar pegawai diperoleh nilai rata-rata 4,33 dengan kriteria jawaban sangat baik, dan indikator hubungan pegawai dengan atasan diperoleh nilai rata-rata 4,27 dengan kriteria jawaban sangat baik. Hal ini terjadi karena para pegawai Kantor Pelayanan Kekayaan Negara dan Lelang Pematangsiantar selalu menjaga hubungan yang baik antar pegawai dan kepada atasan. Pada indikator tingkat pertanggungjawaban pegawai dalam menyelesaikan tugas diperoleh nilai rata-rata 4,43 dengan kriteria jawaban sangat baik. Hal ini terjadi karena pegawai mampu mempertanggungjawabkan setiap pekerjaan yang telah dikerjakan.

Pada dimensi kepemimpinan dengan indikator pimpinan dalam mempengaruhi pegawai diperoleh nilai rata-rata 4,67 dengan kriteria jawaban sangat baik. Hal ini terjadi karena pimpinan Kantor Pelayanan Kekayaan Negara dan Lelang Pematangsiantar memiliki kemampuan untuk mempengaruhi dan memotivasi para pegawai untuk mencapai tujuan instansi. Pada indikator pemimpin dalam melaksanakan tugas pokoknya diperoleh nilai rata-rata 4,57 dengan kriteria jawaban sangat baik. Hal ini terjadi karena pimpinan selalu melaksanakan tugasnya dengan baik. Pada indikator penempatan posisi pegawai sesuai keahlian diperoleh nilai ratarata 4,67 dengan kriteria jawaban sangat baik. Hal ini dapat dilihat dari setiap pegawai di instansi mampu mengelola setiap pekerjaannya dengan baik.

\section{b. Deskriptif Kuantitatif}

\section{1) Regresi Linear Berganda}

Analisis data dalam penelitian ini menggunakan analisis regresi linier berganda. Analisis regresi linier berganda digunakan untuk mengetahui pengaruh variabel bebas (X) dan variabel terikat $(\mathrm{Y})$, dimana $\mathrm{X}$ adalah kemampuan intelektual, etos kerja dan Y adalah kinerja pegawai. Analisis dijalankan dengan melakukan tabulasi jawaban responden pada kuesioner yang telah dijalankan. Maka dilakukan perhitungan mengunakan program aplikasi SPSS untuk memperoleh nilai a dan b dengan notasi sebagai berikut.

Tabel 2

Hasil Regresi Linier Berganda Coefficients $^{\mathrm{a}}$

\begin{tabular}{|c|c|c|c|}
\hline \multirow{2}{*}{ Movel } & \multicolumn{2}{|c|}{ 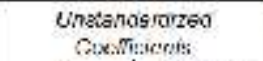 } & \multirow{2}{*}{ 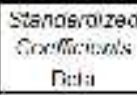 } \\
\hline & $n$ & She $r_{\mathrm{mWw}}$ & \\
\hline $\operatorname{con}$ & -38.572 & 17600 & \\
\hline $\begin{array}{l}1 \text { Kemamougn intelektual } \\
\text { tbos Kera }\end{array}$ & $-\quad .631$ & $--\frac{102}{141}$ & $--\frac{407}{392}$ \\
\hline
\end{tabular}

Dependent Variable: Kinerja Pegawai

Sumber: hasil pengolahan data (SPSS versi 21).

Berdasarkan hasil pengolahan data pada tabel 17 di atas, diperoleh model persamaan $\hat{\mathrm{Y}}=38,572+$ $0,631 X_{1}+0,390 X_{2}$, artinya terdapat pengaruh yang positif antara kemampuan intelektual $\left(\mathrm{X}_{1}\right)$ dan etos kerja $\left(\mathrm{X}_{2}\right)$ terhadap kinerja pegawai $(\mathrm{Y})$ pada Kantor Pelayanan Kekayaan Negara dan Lelang Pematangsiantar.

\section{2) Koefisien Korelasi dan Koefisien Determinasi}

Perhitungan korelasi berupa derajat atau kedalaman hubungan fungsional yang menjelaskan hubungan antar perubah, dinyatakan dengan yang dinamakan koefisien korelasi yang sering disimbolkan dengan $\mathrm{r}$ yang dihitung menggunakan SPSS Versi 21. Hasil koefisien korelasi dan koefisien determinasi dapat dilihat pada tabel berikut ini:

Tabel 3

Hasil Koefisien Korelasi dan Determinasi Model Summary ${ }^{b}$

\begin{tabular}{|c|c|cc|c|}
\hline Sodsl & R & R Square idusted R Square & Sod Eroc of me Estinste \\
\hline 1 & $.725^{\circ}$ & .626 & $\Delta 41$ & 7 illi \\
\hline
\end{tabular}

a. Predictors: (Constant), (Etos Kerja)

(Kemampuan Intelektual)

b. Dependent Variabel: (Kinerja Pegawai)

Sumber: hasil pengolahan data (SPSS versi 21).

Berdasarkan hasil koefisien korelasi pada tabel $18 \mathrm{di}$ atas diperoleh nilai $\mathrm{r}=0,725$, yang artinya terdapat hubungan yang kuat dan positif antara kemampuan intelektual dan etos kerja dengan kinerja pegawai pada Kantor Pelayanan Kekayaan Negara dan Lelang Pematangsiantar, sesuai dengan kriteria koefisien korelasi pada tabel 1. Nilai koefisien determinasi (R Square $)=0,526$, artinya baik tidaknya kinerja pegawai (Y) pada Kantor Pelayanan Kekayaan Negara dan Lelang Pematangsiantar sebesar 52,6\% dapat dijelaskan oleh kemampuan intelektual $\left(\mathrm{X}_{1}\right)$ dan etos kerja $\left(\mathrm{X}_{2}\right)$, sedangkan sisanya sebesar $47,4 \%$ dipengaruhi oleh faktor lain seperti kemampuan kerja, kecerdasan emosional, kecerdasan spiritual, kepribadian, prestasi kerja dan sebagainya yang tidak dibahas dalam penelitian ini.

\section{3) Uji Hipotesis}

a) Uji Simultan (Uji F)

Pengujian ini dilakukan secara simultan yaitu dilakukan untuk menentukan diterima atau ditolaknya hipotesis, pengujian hipotesis dengan kriteria jika $F_{\text {hitung }}>F_{\text {tabel }}$ atau signifikansi $\leq 0,05$ maka $\mathrm{H}_{0}$ ditolak. Untuk menguji kebenarannya maka dilakukan pengujian hipotesis dengan menggunakan program aplikasi SPSS Versi 21.

Tabel 4

Perkiraan $\mathrm{F}_{\text {hitung }}$ ANOVA ${ }^{a}$

\begin{tabular}{|c|c|c|c|c|c|c|}
\hline Wod: & & Sum od bquerzs & $\mathrm{L}$ & Mesw Syuare & 1 & Sig. \\
\hline \multirow{3}{*}{1} & Lives:an & 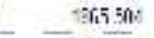 & 3 & 9.75 & TA.SCE & nset \\
\hline & Fisidul & 159463 & 27 & 62.202 & - & \\
\hline & Mal & उ० का? & 20 & & & \\
\hline
\end{tabular}

a. Dependent Variabel: Kinerja Pegawai

b. Predictors: (Constant), Etos Kerja, Kemampuan Intelektual

Sumber: hasil pengolahan data dengan SPSS versi 21 Berdasarkan tabel di atas diperoleh nilai $\mathrm{F}_{\text {hitung }}$ sebesar 14,995 > $\mathrm{F}_{\text {tabel }}$ dengan $(0,05 ; 2$ VS (30-2$1=27)$ ) sebesar 3,35, atau dengan signifikan $0,000<$ $\alpha \quad 0,05$ maka $\mathrm{H}_{0}$ ditolak, artinya kemampuan intelektual dan etos kerja berpengaruh positif dan signifikan terhadap kinerja pegawai pada Kantor 
Pelayanan Kekayaan Negara dan Lelang Pematangsiantar.

\section{b) Uji Parsial (Uji t)}

Pengujian ini dilakukan secara parsial yaitu dilakukan untuk menentukan diterima atau ditolaknya hipotesis, pengujian hipotesis dengan kriteria jika $t_{\text {hitung }}>t_{\text {tabel }}$ atau signifikansi $\leq \alpha 0,05$ maka $\mathrm{H}_{0}$ ditolak. Untuk menguji kebenarannya maka dilakukan pengujian hipotesis dengan menggunakan program aplikasi SPSS Versi 21

Tabel 5

Perkiraan Nilai $t_{\text {hitung }}$ Coefficients $^{\mathrm{a}}$

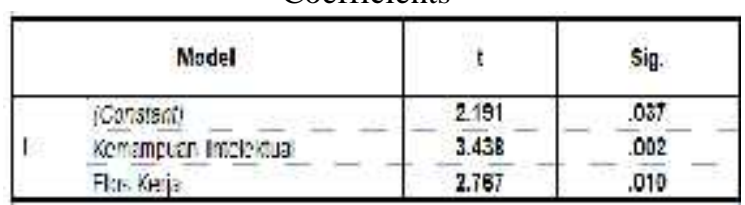

a. Dependent Variabel: Kinerja Pegawai Sumber: hasil pengolahan data dengan SPSS versi 21

Berdasarkan table di atas, diperoleh nilai $t_{\text {hitung }}$ pada variabel $\mathrm{X}_{1}$ (kemampuan intelektual) sebesar $3,438>\mathrm{t}_{\text {tabel }}$ dengan $\mathrm{df}=\mathrm{n}-\mathrm{k}-1 \quad(30-2-1=27)$ sebesar 2,051 atau taraf signifikan $0,002<\alpha 0,05$, maka $\mathrm{H}_{0}$ ditolak, artinya kemampuan intelektual berpengaruh positif dan signifikan terhadap kinerja pegawai pada Kantor Pelayanan Kekayaan Negara dan Lelang Pematangsiantar. Nilai $t_{\text {hitung }}$ pada variabel $\mathrm{X}_{2}$ (etos kerja) sebesar 2,767 $>t_{\text {tabel }}$ dengan df $=n-k-1$, (30-2 $1=27$ ) sebesar 2,051 atau taraf signifikan 0,010 < $\alpha$ 0,05 , maka $\mathrm{H}_{0}$ ditolak, artinya etos kerja berpengaruh positif dan signifikan terhadap kinerja pegawai pada Kantor Pelayanan Kekayaan Negara dan Lelang Pematangsiantar.

\section{Evaluas}

a. Kemampuan Intelektual Pada Kantor Pelayanan Kekayaan Negara dan Lelang Pematangsiantar

Walaupun Kemampuan intelektual memiliki nilai rata-rata 4,16 dengan kriteria jawaban tinggi, namun ada beberapa aspek yang dibawah rata-rata indikator lain, yang pertama yaitu pada dimensi kemahiran berhitung yang diamati dengan indikator tingkat kemampuan dalam berhitung secara cepat bernilai rata-rata 4,07 dengan kriteria jawaban tinggi, cara meningkatkan hal ini sebaiknya pegawai harus lebih sering mengikuti pelatihan rutin.

Pada dimensi pemahaman verbal dengan indikator tingkat kemampuan pegawai dalam menyampaikan pendapat diperoleh nilai rata-rata 3,97 dengan kriteria nilai jawaban tinggi, cara meningkatkannya adalah pimpinan harus berusaha lebih dekat dengan pegawai sehingga pegawai tidak sungkan dalam menyampaikan pendapatnya.

Pada dimensi kecepatan konseptual dengan indikator kemampuan pegawai dalam mengenali kemiripan suatu permasalahan diperoleh nilai ratarata 4,00 dengan kriteria jawaban tinggi, cara meningkatkannya adalah pegawai harus meningkatkan ketelitian dalam bekerja. Pada indikator tingkat kemampuan berfikir pegawai dalam menyelesaikan tugas diperoleh nilai rata-rata 3,83 dengan kriteria jawaban tinggi, cara meningkatkannya adalah dengan pegawai harus lebih rajin bertanya tentang penyelesaian tugas yang belum diketahui, dan menjaga hubungan dengan sesama rekan kerja.

Pada dimensi penalaran deduktif dengan indikator bekerja dengan baik secara fleksibel diperoleh nilai rata-rata 4,10 dengan kriteria jawaban tinggi, cara meningkatkannya adalah pegawai harus menjalin kerjasama antar sesama pegawai dalam mencapai tujuan instansi. Pada dimensi visualisasi ruang dengan indikator membayangkan dan menyelesaikan masalah diperoleh nilai rata-rata 4,07 dengan kriteria jawaban tinggi, cara meningkatkannya adalah pegawai harus melatih diri untuk mampu membayangkan setiap masalah yang akan terjadi dan mampu menyelesaikannya. Pada indikator kemampuan mengerjakan tugas dengan ruangan kerja yang diucah diperoleh nilai rata-rata 4,00 dengan kriteria jawaban tinggi, cara meningkatkannya adalah pimpinan dan pegawai harus meningkatkan keseriusan dan kecakapan dalam mencapai tujuan instansi.

Selanjutnya pada dimensi ingatan dengan indikator ingatan terhadap suatu pekerjaan yang sudah lama tidak dikerjakan diperoleh nilai rata-rata 4,07 dengan kriteria jawaban tinggi, cara meningkatkannya adalah pegawai harus menjalin kerjasama baik antara sesama pegawai maupun kepada pimpinan agar tidak sungkan untuk bertanya dan saling mengingatkan dan memberikan solusi atas pekerjaan yang sudah lama tidak dikerjakan.

Kemampuan intelektual pegawai pada Kantor Pelayanan Kekayaan Negara dan Lelang Pematangsiantar dalam hal ini sudah dikategorikan tinggi. Walaupun sudah dikategorikan tinggi, sebaiknya instansi juga memberikan peluang untuk pendidikan lebih lanjut dan memberikan beasiswa untuk program penyetaraan, memberikan pelatihan secara rutin untuk menggali potensi serta kemampuan pegawai sehingga pegawai memiliki kemahiran dalam menyelesaikan setiap tugasnya.

\section{b. Etos Kerja Pada Kantor Pelayanan Kekayaan}

Negara dan Lelang Pematangsiantar

Walaupun etos kerja memiliki nilai rata-rata 4,38 dengan kriteria jawaban sangat tinggi, namun ada beberapa indikator yang menjadi perhatian seperti pada dimensi kerja adalah rahmat dengan indikator pegawai memiliki rahmat untuk mau bekerja dengan penuh syukur diperoleh nilai rata-rata 4,07 dengan kriteria jawaban tinggi, cara meningkatkannya adalah pegawai harus melatih diri untuk bersyukur dalam setiap pekerjaan yang diterimanya.

Pada dimensi kerja adalah panggilan dengan indikator pegawai memiliki panggilan untuk bekerja dengan penuh integritas diperoleh nilai rata-rata 4,20 dengan kriteria jawaban tinggi, cara meningkatkannya adalah pegawai harus 
meningkatkan kinerja semaksimal mungkin untuk hasil kerja yang produktif dengan integritas yang baik.

Pada dimensi kerja adalah ibadah dengan indikator pegawai memiliki ibadah untuk mau bekerja dengan penuh kecintaan diperoleh nilai ratarata 4,17 dengan kriteria jawaban tinggi, cara meningkatkannya adalah pegawai harus mempunyai keyakinan yang kuat untuk mau bekerja dengan penuh kecintaan dalam menyelesaikan pekerjaannya. Pada dimensi kerja adalah kehormatan dengan indikator pegawai mempunyai kehormatan untuk mau bekerja dengan penuh keunggulan diperoleh nilai rata-rata 4,20 dengan kriteria jawaban tinggi, cara meningkatkannya adalah pegawai harus menggunakan segala kompetensi yang dimilikinya dan meningkatkan keinginan untuk bekerja lebih tekun.

Pada dimensi kerja adalah pelayanan dengan indikator pegawai menerima pelayanan untuk mau bekerja paripurna diperoleh nilai rata-rata 4,17 dengan kriteria jawaban tinggi, cara meningkatkannya adalah pegawai harus mampu melatih diri untuk mau bekerja secara paripurna. Pada indikator pegawai memiliki sikap positif untuk menilai bekerja sebagai bentuk pelayanan diperoleh nilai rata-rata 4,13 dengan kriteria jawaban tinggi, cara meningkatkannya adalah menumbuhkan sikap positif dan mengembangkan sikap kerendahan hat untuk dapat bekerja sama dan melayani sepenuh hati.

Etos kerja pada Kantor Pelayanan Kekayaan Negara dan Lelang Pematangsiantar dalam hal ini dikategorikan sangat tinggi. Walaupun demikian, sebaiknya instansi harus meningkatkan etos kerja bagi para pegawainya dengan lebih memperkuat kerja dengan rahmat, panggilan, ibadah, kehormatan, dan pelayanan agar terciptanya semangat kerja yang tinggi sehingga pegawai dapat memfungsikan etos kerja yang ada dalam dirinya untuk peningkatan kualitas hasil kerjanya.

\section{c. Kinerja Pegawai Pada Kantor Pelayanan Kekayaan Negara dan Lelang \\ Pematangsiantar}

Dari Indikator kinerja pada Kantor Pelayanan Kekayaan Negara dan Lelang Pematangsiantar sudah dalam kategori sangat baik. Hal ini dapat dilihat dari jawaban responden dengan nilai keseluruhan ratarata sebesar 4,49 dengan kriteria jawaban sangat baik.

Namun tentunya ada beberapa indikator yang perlu diperhatikan karena nilainya masih dibawah rata-rata, seperti pada dimensi kuantitas pada indikator sikap pegawai dalam menangani volume pekerjaan yang luar biasa banyaknya diperoleh dengan nilai rata-rata 4,20 dengan kriteria jawaban baik, pada indikator tingkat pencapaian target kerja pegawai diperoleh dengan nilai rata-rata 4,37dengan kriteria jawaban sangat baik. Cara meningkatkannya adalah dengan memberikan perhatian khusus kepada setiap pegawai yang bekerja lembur demi menyelesaikan pekerjaannya dan pegawai sendiri harus melatih dirinya untuk tetap semangat dalam mencapai target kerja.

Pada dimensi kualitas dengan indikator pegawai bekerja sesuai standar yang ditentukan diperoleh nilai rata-rata 4,33 dengan kriteria jawaban sangat baik. Cara meningkatkannya adalah dengan memotivasi pegawai untuk bekerja sesuai dengan standar yang telah ditentukan. Pada indikator tingkat mutu hasil kerja pegawai dengan nilai rata-rata 4,43 dengan kriteria jawaban sangat baik. Cara meningkatkannya adalah pegawai harus lebih teliti dalam bekerja, dan lebih memperhatikan kerapian pekerjaan untuk memperoleh kualitas kerja yang baik.

Pada dimensi ketepatan waktu dengan indikator pegawai dalam menyelesaikan pekerjaan dengan tepat waktu diperoleh nilai rata-rata 4,40 . Cara meningkatkannya adalah sebaiknya pegawai memiliki sikap konsistensi dalam menyelesaikan pekerjaannya dengan tepat waktu. Pada indikator tingkat efisiensi waktu pegawai dalam menyelesaikan pekerjaan diperoleh nilai rata-rata 4,27. Cara meningkatkannya adalah pegawai harus lebih menghargai waktu agar setiap pekerjaan yang diberikan dapat terselesaikan dengan baik dan tepat waktu.

Pada dimensi orientasi pelayanan dengan indikator tingkat pelayanan yang diberikan pegawai diperoleh nilai rata-rata 4,40 dengan kriteria jawaban baik. Cara meningkatkannya adalah sebaiknya pegawai lebih memperhatikan sikap dalam memberikan pelayanan. Pada indikator sikap pegawai dalam memberikan pelayanan diperoleh nilai rata-rata 4,33. Cara meningkatkannya adalah pegawai harus memperhatikan sikap yang baik dan sopan serta ketepatan waktu dalam memberikan pelayanan kepada masyarakat.

Pada dimensi integritas dengan indikator kemampuan pegawai dalam instansi diperoleh nilai rata-rata 4,37. Cara meningkatkannya adalah dengan mengadakan pelatihan secara rutin untuk mengasah kemampuan pegawai dalam melaksanakan tugas. Pada dimensi disiplin dengan indikator pemberian sanksi jika ada pegawai yang tidak disiplin diperoleh nilai rata-rata 4,27. Cara mengatasinya adalah pimpinan harus lebih ketat dalam memberikan sanksi terhadap pegawai yang melanggar peraturan.

Pada dimensi kerjasama dengan indikator hubungan kerjasama antar pegawai diperoleh nilai rata-rata 4,33. Cara meningkatkannya adalah sebaiknya pegawai lebih meningkatkan dan menjaga hubungan antar sesama rekan kerja. Pada indikator hubungan pegawai dengan atasan diperoleh nilai rata-rata 4,27. Cara meningkatkannya adalah sebaiknya pimpinan lebih berusaha mendekatkan diri dengan bawahan. Pada indikator tingkat pertanggungjawaban pegawai dalam menyelesaikan tugas diperoleh nilai rata-rata 4,43. Cara mengatasinya adalah pegawai dan pimpinan harus menjaga hubungan dan menjalin kerjasama yang baik.

Kinerja pegawai pada Kantor Pelayanan Kekayaan Negara dan Lelang Pematangsiantar 
dalam hal ini sudah dikategorikan sangat baik. Walaupun sudah dikategorikan sangat baik, sebaiknya pimpinan harus berusaha menjalin hubungan yang dekat dengan pegawai dan memberikan pembinaan secara formal dengan memotivasi pegawai agar dapat bekerja dengan lebih baik.

\section{KESIMPULAN DAN SARAN}

\section{Kesimpulan}

a. Hasil analisis desktiptif kualitatif kemampuan intelektual pada Kantor Pelayanan Kekayaan Negara dan Lelang Pematangsiantar berada pada rata-rata 4,16 yang berkriteria tinggi. Nilai ratarata tertinggi sebesar 4,33 dengan kriteria sangat tinggi berada pada dimensi kemahiran berhitung dengan indikator tingkat kemampuan dalam mengerjakan tugas, pada dimensi pemahaman verbal dengan indikator kemampuan memahami apa yang dibaca, dan pada dimensi penalaran induktif dengan indikator usaha yang dilakukan dalam memecahkan pekerjaan yang sulit. Sedangkan kelemahan dengan nilai rata-rata sebesar 3,83 dengan kriteria tinggi pada dimensi kecepatan konseptual dengan indikator tingkat kemampuan pegawai dalam menyelesaikan tugas sebagai dimensi pekerjaan.

b. Hasil analisis deskriptif kualitatif etos kerja pada Kantor Pelayanan Kekayaan Negara dan Lelang Pematangsiantar berada pada rata-rata 4,38 dengan kriteria sangat tinggi. Nilai rata-rata tertinggi sebesar 4,57 dengan kriteria nilai sangat tinggi berada pada dimensi kerja adalah panggilan dengan indikator pegawai memiliki panggilan untuk mau bekerja dengan tuntas dan pada dimensi kerja adalah seni dengan indikator pegawai memiliki seni untuk mau bekerja dengan penuh kreativitas. Sedangkan kelemahan dengan nilai rata-rata 4,07 dengan kriteria jawaban tinggi berada pada dimensi kerja adalah rahmat dengan indikator pegawai memiliki rahmat untuk mau bekerja dengan penuh syukur.

c. Hasil analisis deskriptif kualitatif kinerja pegawai pada Kantor Pelayanan Kekayaan Negara dan Lelang Pematangsiantar berada pada nilai ratarata jawaban keseluruhan 4,49 dengan kriteria sangat baik. Nilai rata-rata tertinggi sebesar 4,67 dengan kriteria nilai sangat baik berada pada dimensi biaya dengan indikator kemampuan pegawai dalam mengalokasi biaya pekerjaan, pada dimensi integritas dengan indikator etika pegawai dalam instansi dan konsistensi pegawai dalam bekerja, pada dimensi kepemimpinan dengan indikator pimpinan dalam mempengaruhi pegawai dan pada indikator menempatkan posisi pegawai sesuai dengan keahlian. Sedangkan kelemahan dengan nilai rata-rata sebesar 4,20 dengan kriteria jawaban baik berada pada dimensi kuantitas dengan indikator pegawai menangani volume pekerjaan yang luar biasa banyaknya.

d. Hasil analisis regresi linear berganda yang dihitung melalui program SPSS versi 21 sebagai berikut $\hat{Y}=38,572+0,631 \mathrm{X}_{1}+0,390 \mathrm{X}_{2}$, artinya terdapat pengaruh yang positif antara kemampuan intelektual $\left(\mathrm{X}_{1}\right)$ dan etos kerja $\left(\mathrm{X}_{2}\right)$ terhadap kinerja pegawai (Y) pada Kantor Pelayanan Kekayaan Negara dan Lelang Pematangsiantar.

e. Hasil analisis korelasi diperoleh nilai $\mathrm{r}$ sebesar 0,725 , yang artinya terdapat hubungan yang kuat dan positif antara kemampuan intelektual $\left(\mathrm{X}_{1}\right)$, dan etos kerja $\left(\mathrm{X}_{2}\right)$, dengan kinerja pegawai $(\mathrm{Y})$ pada Kantor Pelayanan Kekayaan Negara dan Lelang Pematangsiantar. Kemudian diperoleh nilai koefisien determinasi (R Square) $=0,526$, artinya baik tidaknya kinerja pegawai (Y) pada Kantor Pelayanan Kekayaan Negara dan Lelang Pematangsiantar sebesar 52,6\% dapat dijelaskan oleh kemampuan intelektual $\left(\mathrm{X}_{1}\right)$ dan etos kerja $\left(\mathrm{X}_{2}\right)$, sedangkan sisanya sebesar $47,4 \%$ dipengaruhi oleh faktor lain seperti motivasi, komunikasi, lingkungan kerja, kepuasan kerja dan lain-lain.

f. Hasil uji hipotesis secara simultan diperoleh nilai $F_{\text {hitung }}$ sebesar 14,995 sedangkan $F_{\text {tabel }}$ dengan $(0,05 ; 2$ vs 27$)$ sebesar 3,35 atau taraf signifikan sebesar $0,000<\alpha 0,05$, maka $\mathrm{H}_{0}$ ditolak, artinya kemampuan intelektual dan etos kerja berpengaruh positif dan signifikan terhadap kinerja pegawai pada Kantor Pelayanan Kekayaan Negara dan Lelang Pematangsiantar.

g. Hasil uji hipotesis secara parsial diperoleh nilai $\mathrm{t}_{\text {hitung }}$ pada variabel $\mathrm{X}_{1}$ (kemampuan intelektual) sebesar 3,438 sedangkan $t_{\text {tabel }}$ dengan $\mathrm{df}=\mathrm{n}-\mathrm{k}-1$ $(30-2-1=27)$ sebesar 2,051 atau taraf signifikan $0,002<\alpha 0,05$, maka $\mathrm{H}_{0}$ ditolak, artinya kemampuan intelektual berpengaruh positif dan signifikan terhadap kinerja pegawai pada Kantor Pelayanan Kekayaan Negara dan Lelang Pematangsiantar. Sedangkan pada variabel $\mathrm{X}_{2}$ (etos kerja) diperoleh nilai $t_{\text {hitung }}$ sebesar 2,767 sedangkan $t_{\text {tabel }}$ dengan $\mathrm{df}=\mathrm{n}-\mathrm{k}-1,(30-2-1=27)$ sebesar 2,051, atau taraf signifikan $0,010<\alpha$ 0,05 , maka $\mathrm{H}_{0}$ ditolak, artinya etos kerja berpengaruh positif dan signifikan terhadap kinerja pegawai pada Kantor Pelayanan Kekayaan Negara dan Lelang Pematangsiantar.

\section{Saran}

a. Kemampuan intelektual pegawai pada Kantor Pelayanan Kekayaan Negara dan Lelang Pematangsiantar masih perlu ditingkatkan, untuk itu sebaiknya instansi memberikan peluang untuk pendidikan lebih lanjut juga memberikan beasiswa untuk program penyetaraan, dan memberikan pelatihan secara rutin untuk menggali potensi serta kemampuan pegawai sehingga pegawai memiliki kemahiran dalam menyelesaikan setiap tugasnya.

b. Etos kerja pada Kantor Pelayanan Kekayaan Negara dan Lelang Pematangsiantar masih perlu ditingkatkan karena masih ada indikator yang belum optimal. Untuk itu instansi sebaiknya meningkatkan etos kerja bagi para pegawainya dengan lebih memperkuat kerja dengan rahmat, panggilan, ibadah, kehormatan, dan pelayanan 
agar terciptanya semangat kerja yang tinggi sehingga pegawai dapat memfungsikan etos kerja yang ada dalam dirinya untuk peningkatan kualitas hasil kerjanya.

c. Kinerja pegawai pada Kantor Pelayanan Kekayaan Negara dan Lelang Pematangsiantar masih perlu ditingkatkan karena masih ada indikator yang belum optimal. Untuk mengoptimalkan kinerja pegawai, maka instansi sebaiknya memberikan perhatian khusus kepada setiap pegawai yang bekerja lembur demi menyelesaikan pekerjaan, mengadakan pelatihan secara rutin, dan memberikan sanksi yang tegas kepada setiap pegawai yang melanggar peraturan. Pimpinan Kantor Pelayanan Kekayaan Negara dan Lelang Pematangsiantar juga sebaiknya lebih menjalin hubungan yang lebih akrab dengan pegawai dan memberikan pembinaan formal dengan memotivasi pegawai agar bekerja dengan lebih baik serta memberikan kesempatan untuk berinovasi sehingga menimbulkan kreativitas dalam bekerja.

d. Sehubungan dengan keterbatasan-keterbatasan yang ada pada penulis, penelitian ini masih jauh dari kesempurnaan dan masih terdapat kelemahan-kelemahan, serta belum dapat menggungkapkan seluruh variabel yang meningkatkan kinerja pegawai pada Kantor Pelayanan Kekayaan Negara dan Lelang Pematangsiantar. Sebagai bahan masukan untuk penelitian selanjutnya, perlu memperbanyak variabel penelitian seperti kemampuan kerja, kecerdasan emosional, kecerdasan spiritual, kepribadian, dan semangat kerja.

\section{E. DAFTAR PUSTAKA}

Anoraga, Pandji. 2009. Manajemen Bisnis. Jakarta: Rineka Cipta.

Dessler, Gary. 2006. Manajeman Sumber Daya Manusia. Jakarta: Indeks.

Gibson, James, L. 2000. Organisasi, Perilaku, Struktur dan Proses. Edisi V. Cetakan ketiga. Jakarta: Penerbit Erlangga.

Goleman, Daniel. 2002. Working With Emotional Intelligence. Jakarta: PT. Gramedia Pustaka Utama.

Mathis, Robert L. dan John H. Jackson. 2006. Human Resource Management. Edisi X. Jakarta: Salemba Empat.

Peraturan Pemerintah Republik Indonesia Nomor 46 Tahun 2011 tentang Penilaian Prestasi Keja PNS.

Rivai, Veithzel. 2005. Manajemen Sumber Daya Manusia untuk Perusahaan dari Teori ke Praktik. Jakarta: PT Raja Grafindo Persada.

Robbins, Stephen P. 2001. Perilaku Organisasi. Edisi 8. Jakarta: Prentice Hall.

2003. Perilaku Organisasi, Jilid 2. Jakarta:

PT. Indeks Kelompok Gramedia.

Sinamo. 2005. Delapan Etos Kerja Profesional: Navigator Anda Menuju Sukses. Bogor: Grafika Mardi Yuana.

Tasmara, Toto. 2002. Etos Kerja Islami. Jakarta: Gema Insani Press. 